\title{
EXTENSION OF THE CONSTITUTIONAL COURT AUTHORITY IN THE DISSOLUTION OF CORRUPTED POLITICAL PARTIES
}

\author{
Abdul Hakim Siagian \\ Faculty of Law, Muhammadiyah University of North Sumatra \\ abdulhakim@umsu.ac.id
}

\begin{abstract}
After the amendment of the Constitution of the Unitary State of the Republic of Indonesia in 1945 changed the constitutional system in Indonesia, since the birth of the Constitutional Court of the Republic of Indonesia which was authorized to adjudicate the dissolution of political parties up to now has never been done by the Constitutional Court, the debate over the dissolution of political parties is also seen as a violation of the rights of political parties. Human rights as the right to assemble and associate, the state administration thought continues to develop about the dissolution of corrupt political parties by giving authority to the Constitutional Court.This research was conducted with normative legal research whose data is sourced from secondary data and since this research data is secondary data, it is included in the type of normative legal research. The nature of this research is descriptive, which aims to provide an overview of social phenomena about the expansion of the authority of the Constitutional Court in the Disbanding of a Corrupt Political Party. Sources of research data in the form of primary legal materials, secondary legal materials and tertiary legal materials. The method of data collection is done using document study techniques, which are analyzed using qualitative analysis techniques.
\end{abstract}

Keywords: Constitutional Court, Disbandment of Political Parties, Corrupt Party. INTRODUCTION

The democratic system at present is commonly applied in countries in the world in the system of government. This democracy is closely related to the principle of popular sovereignty which according to Kusnardi and Harmaily Ibrahim teaches that the highest power in a country is owned and implemented by the people. ${ }^{1}$ Likewise, in democracy, where the government of a country is placed on the people who are fully represented by certain people (people's representatives) who are in the people's representative institutions. ${ }^{2}$ So the existence of democracy in a country's government system can be demonstrated by the existence of people's representative institutions in that country, as practiced in Indonesia as contained in Article 1 paragraph (2) of the 1945 Constitution.

The practice of democracy in a country's government system is not only related to the people's representative institutions, but also related to the existence of political parties. Schattscheider even stated the link between political parties and democracy by stating that democracy is determined by political parties. ${ }^{3}$ Therefore, the existence of political parties in a country needs to be strengthened its institutionalization in order to realize government

\footnotetext{
${ }^{1}$ Jimly Asshiddiqie, Pengantar Ilmu Tata Negara, (Jakarta: RajawaliPers, 2009), p. 414.

${ }^{2}$ Soehino, Ilmu Negara, Cetakan Ke-V, (Yogyakarta: Liberty, 2005), p. 27.

3 Jimly Asshiddiqie, Kemerdekaan Beserikat, Pembubaran Partai Politik dan Mahkamah
} Konstitusi, Sekretariat Jenderal dan Kepaniteraan Mahkamah Konstitusi Republik Indonesia, Jakarta, p. 52. 
and democratic political life.

The existence of political parties prior to reform in Indonesia was very limited, as indicated by only 2 (two) political parties participating in the General Elections at the time, namely the United Development Party (PPP) and the Indonesian Democratic Party (PDI). Meanwhile the Work Group itself declared itself not a party even though in the reform era Golkar transformed itself into a political party. Political parties began to develop freely in the era of reform in which the 1999 elections were followed by 48 political parties. ${ }^{4}$ This shows that since the beginning of the reform era until now there has been no longer a restriction on freedom to form political parties, as long as their formation and existence are not contrary to positive law in Indonesia.

Political parties themselves are a form of freedom of association and assembly of Indonesian citizens, which is guaranteed constitutionally as one of the human rights in Article $28 \mathrm{E}$ paragraph (3) of the 1945 Constitution. Guarantees of freedom of association are also regulated in Article 24 of Law No. 39 of 1999 concerning Human Rights (Human Rights Law) which states that the right for every Indonesian citizen to associate, gather, and hold opinions by forming groups, one of which is in the form of political parties.

${ }^{4}$ Putu Eva Served Antari, Journal of Udayana's Masters in Law, The Authority to Disband a Political Party by the Constitutional Court Judging from the Perspective of Human Rights (HAM), Volume 7 Number 3, (2014).
As a public legal entity, a political party, has several important relating to the function of political parties. In general Roy C. Macridis put forward the functions of political parties including: representation (representation) of the people; conversion and aggregation; integration (participation, outreach, mobilization); persuasion, repression, recruitment, election of leaders, policy considerations and formulation, and control of the government. ${ }^{5}$

Basically the entire function has an inseparable role from its management, for that there is no harm in managing political parties that must be the main example for the community in playing their role as representatives of the community, all forms of behavior and actions of members of political parties must reflect the personality that noble by not committing a despicable act especially crime. A crime has a correlation to a form of responsibility for the crime itself. For this reason, political party organizations in the form of legal entities must have special responsibility for acts related to criminal acts.

Mas Achmad Santosa proposed two stages to determine the criminal liability of a legal entity. In the first stage there are 3 (three) criteria that need to be considered, first, whether a

5 Roy C Macridis, Introduction: The History, Functions, and Typology of Parties Contemporary Trends and Ideas ", in Ichlasul Amal, The Latest Theories of Political Parties (Yogyakarta : PT Tiara Wacana Yogya, 1998), p. 27. 
legal entity can be the object of the relevant legal norms, second, whether the management of the legal entity concerned has authority over the people in the organization (including the perpetrators physical or physical dader ) and third, whether the management or legal entity concerned can be said to "accept" or "tend to accept" the deviant behavior charged.

The second stage to prove a legal entity's criminal act is first, if the management of a legal entity has known the criminal act that has been committed, does management have the authority to stop the actions of the physical offender and secondly, if management has the authority to do so but does not take precautions, then such legal entities can be categorized as committing criminal acts. ${ }^{6}$

The criminal acts intended in this case are criminal acts that are closely related to acts of corruption involving political parties as legal entities. In the Big Indonesian Dictionary, corruption is defined as a bad deed, which is equated with embezzlement of money, receipt of bribes and so on. ${ }^{7}$ Corruption is an act aimed at enriching oneself or another person whether committed by a corporation or a legal entity that can harm the country's finances or the country's economy.

Corporate actions involving a legal entity are closely related to the

6 Mas Achmad Santosa, Good Governance dan Hukum Lingkungan, (Jakarta: ICEL, 2001), p. 241.

7 Poerwadarminta, Indonesian General Dictionary, 1976. conception of civil law and criminal law, but if the law is a political organization, the legal entity is included in the conception of state administration, so that political parties are categorized as legal entities. According to Mardjono Reksodiputro, the notion of a legal entity (rechtpersoon) is a concept of civil law, it is necessary to think of civil law as a way of taking it into the criminal law as stated below:

In the beginning, in civil law there were also differences of opinion whether a legal entity could carry out acts against the law (overechtmatig

handelen). However, through the principles of propriety (doelmatigheid) and justice (bilijkheid) as the main basis, then the law of civil law accepts that a legal entity must be considered guilty is an act against the law, especially in economic traffic. This teaching is based on the idea that what is done by the board must be accountable to the legal entity, because the board in acting does not do it on its own rights or authority, but on the rights or authority of the legal entity concerned. Thus, the legal entity also cannot escape from mistakes made by the board. Deliberation (dolus) or negligence (Culpa) of the management must be regarded 
as intentional and negligence of the legal entity itself. ${ }^{8}$

In criminal law there are at least three main teachings known in the responsibility of corporate or legal entity criminal acts, the three teachings are: identification doctrine, strict liability doctrine and vicarious liability doctrine. ${ }^{9}$

The doctrine of identification explains that the conduct of the management or employee of a corporation or legal entity is identified as the act of the corporation itself. ${ }^{10}$

Corporations or legal entities are artificial entities, so they can only act through agents (management) of a legal entity, according to this doctrine the agents (management) in a legal entity are considered as directing mind or alter go. The actions of the individuals are then associated with legal entities. If individuals are given the authority to act on behalf of legal entities and carry out the activities of legal entities, the mens rea of individuals is the mens rea of

8 Mardjono Reksodiputro, Pembaruan Hukum Pidana, Kumpulan Karangan, Buku Keempat, (Jakarta: Pusat Pelayanan Keadilan dan Pengabdian Hukum Lembaga Kriminologi Universitas Indonesia, 2007), p. 106-107.

99 In addition to these three teachings, Sutan Remy Sjahdeini put forward four other doctrines, namely: Doctrine of Delegation, Doctrine of Aggregation, The Corporat Culture Model and Doctrine Reactive Corporate Fault. Sutan Remy Sjahdeini, Pertanggungjawaban Pidana Korporasi, (Jakarta: Grafiti Pers, 2006), p. 97113.

$$
{ }^{10} \text { Mardjono Recosudiputro, Op.Cit, }
$$
p. 107. legal entities. ${ }^{11}$ In other words, if the criminal act is committed by those who are derecting minds of the corporation / legal entity, then criminal liability can be borne by the corporation / legal entity. $^{12}$

According to the strict liability doctrine, criminal liability can be imposed on the perpetrators of the relevant criminal acts with no need to prove an error (intentional or negligence) on the culprit or referred to as absolute liability. ${ }^{13}$ Hamzah Hatrik quoted LP Curzon as presenting three reasons for adopting this doctrine. The reasons are as follows: ${ }^{14}$

1. It is essential to ensure that certain important rules are adhered to for the welfare of society

2. Proving the existence of mens rea will be difficult for violations related to social welfare.

3. The high level of social danger caused by the act in question.

Barda Nawawi Arief said that most strict liabilities are found in the offenses stipulated in the statutory offence, regulatory offence , which are generally offenses related

\footnotetext{
11 Dwidja Priyatno, 2004, Kebijakan Legislasi Tentang Sistem Pertanggungjawaban Pidana Korporasi Indonesia, Bandung: CV Utomo, p. 89.

${ }^{12}$ Sutan Remy Sjahdeini, Op.Cit., p. 100 ${ }^{13}$ Ibid., p. 78 .

14 Hamzah Hatrik, Asas Pertanggungjawaban Korporasi dalam Hukum Pidana di Indonesia (Strict Liability dan Vicarius Liability), (Jakarta: Grafindo Persada, 1996), p. 113.
} 


\section{LAW REVIEW E-ISSN:2722-3663

to public welfare. ${ }^{15}$

In line with that according to

Romli Atmasmita, the legislators have determined if the rules regarding strict liability crimes can be enforced as follows:

1. Crimes committed are not due to serious crimes

2. The threat of punishment is mild

3. The requirement for mens rea will hamper the purpose of the legislation

4. Crimes committed directly are a coercion of the rights of others

5. According to the law applicable mens rea is $\mathrm{k}$ asuistis do not need to be proven .

In connection with the doctrine of strict liability, it is important to consider the opinion of John C. Coffe as quoted by Barda Nawawi Arief, who states that a corporation is not responsible only because an agent commits a prohibited act (actus reus). But it must be proven three elements:

1. The agent (member) has committed a crime.

2. His acts were carried out within the scope of his authority.

3. Done with the purpose / intentionally to benefit the corporation.

In addition to the above conception of strict liability, there is also known

criminal liability called vicarius

liability, which is a person's liability without personal error, is responsible

\footnotetext{
Barda Nawawi Arief, Perbandingan Hukum Pidana, (Jakarta: Rajawali Pers, 1990), p. 29.
}

for the actions of others ( a vicarius liability is one where in one person, even without personal fault, is more liable for the conduct of another).

\section{METHOD}

This type of research can be divided into normative legal research and empirical / sociological legal research. Normative legal research is research whose data is sourced from secondary data and since this research data is secondary data, it is included in the type of normative legal research. The nature of this research is descriptive, which aims to provide an overview of social phenomena about the expansion of the authority of the Constitutional Court in the Disbanding of a Corrupt Political Party. Sources of research data in the form of primary legal materials, secondary legal materials and tertiary legal materials. The method of data collection is done using document study techniques, which are analyzed using qualitative analysis techniques.

\section{DISCUSSION}

\section{Mechanism for the Disbandment of Political Parties by the Constitutional Court}

The development of political parties in Indonesia experienced ups and downs along with the changing political and administrative dynamics. The development of political parties can be seen in terms of the number of political parties and party ideology. ${ }^{16}$ In terms of numbers, at each

16 Widayanti, "Dissolution of
Political Parties in the Indonesian


general election held, sometimes it multiplies, sometimes decreases. In terms of ideology, in its development now there are religious and nationalist ideologies. Legislation prohibits political parties with communist ideology or Marxism Leninism. Independence of association and assembly guaranteed by the 1945 Constitution of the Republic of Indonesia encouraged various parties to establish political parties. The requirements regarding the establishment of political parties have been discussed in the previous subchapter.

Besides fulfilling pe rsyaratan, political parties have rights and obligations. In addition there are certain restrictions that cannot be violated by political parties. Violation of the prohibition can result in a political party being dissolved. Law Number 2 of 2008 concerning Political Parties contains prohibitions that must not be violated, namely in Article 40:

(1) Political Parties are prohibited from using the same name, symbol or image as:

a. the flag or coat of arms of the Republic of Indonesia;

b. the number of state institutions or Government symbols;

c. names, flags, symbols of other countries or international institutions / bodies ;

Administrative System", Journal of the Law of Sultan Agung Islamic University, Volume XXVI, Number 2, August, (2011), p. 625 . d. names, flags, symbols of separatist movements or banned organizations;

e. a person's name or picture; or

f. which has similarity in principle or in whole with the name, symbol or image of another Political Party.

(2) Political Parties are prohibited :

a. conduct activities that are contrary to the 1945 Constitution of the Republic of Indonesia and by statutory regulations; or

b. conduct activities that endanger the integrity and safety of the Unitary Republic of Indonesia.

(3) Political parties are prohibited from:

a. receive from or give to foreign parties donations in any form contrary to the laws and regulations;

b. accepting donations in the form of money, goods, or services from any party without a clear identity;

c. accepting donations from individuals and / or companies / business entities exceeding the limits specified in the legislation;

d. requesting or receiving funds from state-owned enterprises, regionallyowned enterprises, and villageowned or other business entities with other names; or

e. use the factions in the People's Consultative Assembly, the People's

Representative Council, the Provincial Regional People's Representative Council, and the District / City Representative Council as a source of funding for political parties. 
(4) Political parties are prohibited from establishing business entities and / or owning shares of a business entity.

(5) Political Parties are prohibited from adhering to and developing and spreading the teachings or understandings of communism / marxism-Leninism.

Violation of the prohibition does not necessarily cause the political parties concerned to be threatened with liquidation. Sanctions for political parties which are proven to violate the prohibitions are administrative, some are civil, and there are criminal sanctions.

These forms of sanctions can be interpreted from the provisions of Article 47 paragraph (5) of Law Number 2 of 2008 namely that violations of the provisions referred to in Article 40 paragraph (3) letter e are subjected to administrative sanctions imposed by the agency / institution tasked with safeguarding the honor and dignity of political parties and their members. In addition to these provisions, other forms of sanctions are also contained in Article 48 of Law Number 2 of 2008, namely: (1) Political Parties that already have legal entities violate the provisions of Article 40 paragraph (1) subject to administrative sanctions in the form of a suspension of management by the state court. (2) Violations of the provisions referred to in Article 40 paragraph (2) are subject to administrative witnesses in the form of a temporary suspension of the relevant Political Party in accordance with their level by a district court for a maximum of 1 (one) year. (3) Parties which have temporarily suspended as described in paragraph (2) and the offense again against the provisions laid down as referred to in Article 40 paragraph (2) dibubarka $n$ with the Constitutional Court's decision. (4) In the event of a violation of the provisions as referred to in Article 40 paragraph (3) letter $a$, the management of the relevant Political Party shall be liable to a maximum imprisonment of 2 (two) years and a fine of 2 (two) times the amount of the funds received. . (5) In the event of a violation of the provisions as referred to in Article 40 paragraph (3) letter b, letter c, and letter, the management of the political party who is in a crime shall be liable to Ac maximum imprisonment of 1 (one) year and a fine of 2 (two) times the amount of funds received. (6) The violation of the provisions referred to in Article 40 paragraph (4) shall be subjected to administrative sanctions in the form of a temporary suspension of the management of the Political Party concerned in accordance with their level by a district court and their assets and shares confiscated to the state. (7) Violations of the provisions referred to in Article 40 paragraph (5) shall be subject to sanctions for the dissolution of political parties by the Constitutional Court.

The procedure for submitting dissolution of political parties to the Constitutional Court is regulated in the provisions of Article 68 paragraph (1) and paragraph (2) of Law Number 24 of 2003 concerning the Constitutional Court which 
states: (1) The applicant is the Government. (2) The applicant must describe clearly in his petition the ideology, principles, objectives, programs and activities of the relevant political parties, which are considered to be in conflict with the 1945 Constitution of the Republic of Indonesia. Decision of the Constitutional Court regarding the application for the dissolution of political parties must shall be decided not later than 60 (sixty) working days after the application is recorded in the Constitutional Case Registration. In the provisions of Article 68 it is not clear what type of violations can be used as a basis for the Government to demand the dissolution of a political party. However, it can be interpreted that the evidence used to assess the application submitted by the Government in this case are: 1 . statutes 2. bylaws 3. reports on the activities of the political parties concerned. If one of the three found evidence of things things that are contrary to the Constitution, the Constitutional Court to dissolve the Political Parties concerned by the decision yan $g$ is final and binding.

At the present time, the Constitutional Court has never deciding the case dissolution of political parties, because the petition for dissolution of political parties has not been submitted to the Constitutional Court by the Government. This can be understood, because the dissolution of political parties can not only be carried out with a request to the Constitutional Court but the dissolution of political parties can occur due to other reasons as regulated in Law Number 2 Year 2008. Article 41 of Law Number 2 Year 2008 only determine that a political party is dissolved if: a. disperse themselves on their own decisions; b. merge with other political parties, or; c. dissolved by the Constitutional Court. So far, political parties have broken up with the excuse of dissolving themselves on their own decisions or merging themselves with other political parties. The dissolution of political parties in the history of Indonesian state administration began in the period of guided democracy.

Guided democracy is a democracy that was adopted in Indonesia during the reign of President Soekarno $\mathrm{P}$ asca Presidential Decree July 5, 1959 until its fall in 1966 following the emergence of the New Order. One of President Soekarno's political policies was to simplify the numerous political parties in Indonesia which were inherited from the political policies of the previous party listed in the Government Announcement on November 3, 1945, signed by the Vice President Mohamad Hatta. The Government's announcement on November 3, 1945 was the first regulation in the field of membership in Indonesia after independence which had given birth to a multi-party system with multiple ideologies. The notice was revoked by President Soekarno with Presidential Decree Number 7 of 1959 concerning Requirements for Simplification of Party Parties (State Gazette of the Republic of Indonesia Number 149 of 1959, Supplement to State Gazette of the Republic of 
Indonesia Number 1916) whose implementation was regulated in Presidential Regulation Number 13 of 1960 Regarding Recognition, Oversight and Dissolution of Parties.

Provisions regarding the dissolution of political parties according to Article 6 of Presidential Decree Number 7 of 1959 and Article 9 of Presidential Regulation Number 13 of 1960 are as follows: 1. The institution authorized to prohibit and / or dissolve political parties is the President after hearing the considerations of the Supreme Court. 2. Reasons for the banning and / or dissolution of political parties are: a. The principles and objectives are in conflict with the principles and objectives of the state. b. The program intends to overhaul the principles and objectives of the country. $c$. It is in revolt because its leaders have participated in rebellions or have clearly provided assistance, while the party has not officially blamed the actions of its members. d. Failure to meet the other conditions stipulated in this Presidential Decree.

In the era of guided democracy several political parties with Presidential Decrees, such as Presidential Decree Number 29 of 1961, rejected the recognition of PSIIAbikusno, PR-Bebasa, PRI, and PRN-Djody, as well as the dissolution of the Masyumi and PSI parties. At the time of the new order government began with the dissolution of the Indonesian Communist Party (PKI) including parts of its organization from the central to the regional level along with all organizations that were of the same / protected / shelter under it, as well as the statement as a banned organization in the entire territory of the Republic of Indonesia, on March 12, 1966 with Presidential Decree Number 1/3/1966.

There is the New Order government policies dissolution / banning of political parties evolved from dissolution indirectly through fusion affirmed by the law of political parties and groups of works, up to a policy that does not megenal dissolution of political parties through legislation undag political parties and groups work Yag has determined that only PPP, PDI and Golkar can live. Politics of the New Order party law is a fixed limited multiparty policy (the number is limited to only three, not more or less less) accompanied by a "single principle" policy and a "floating mass" policy, with the logic of error on the board, not on the party, so there is no known dissolution of political parties, but the freezing of political party management.

\section{Expansion of the Authority to Disband a Corrupt Political Party by the Constitutional Court}

Indonesia as a democratic
country guarantees a political party which is one manifestation of the right to freedom of association as reflected in Article 28 of the 1945 Constitution of the Republic of Indonesia (URI NRI). These political parties are urgently needed because political parties have position (status) and role (role) as a very strategic link 


\section{LAW REVIEW $\begin{aligned} & \text { E-ISSN: 2722-3663 } \\ & \text { Volume } 1, \text { Issue 2, May 2020 }\end{aligned}$}

between government processes with citizens. Even a good party system will determine the operation of the constitutional system based on the principle of checks and balances in the broadest sense. In the political context, especially in power relations, political parties have changed the relationship between the people and the authorities from initially disqualifying the people from the stage of political power, to positioning the people as actors and important axis in the relationship, even in contemporary democracy the existence of political parties has become the main instrument the people to compete and gain control over political institutions. Because of political parties is a reflection of the freedom of association (freedom of association) and assembly ( freedom of assembly ) as a manifestation of freedom of thinking (freedom of thought) as well as the freedom of expression (freedom of expression), its existence is protected by the state constitution in a constitutional democracy.

However, freedom of association has the limitations needed in a democratic society for national security and state safety, to prevent crime, and to protect other rights and freedoms. The limitation is also a form of supervision of political parties as a consequence of the rule of law adopted by a country, including by the Indonesian state. In practice in Indonesia, supervision of political parties is carried out in two ways, namely through elections and through the dissolution of political parties. With regard to the dissolution of political parties, the Constitutional Court (MK) which was born in 2003 based on Article 25 C paragraph (1) of the 1945 Constitution of the Republic of Indonesia has been given a mandate by the constitution to dissolve political parties. In general, the reason for the dissolution of political parties by the Constitutional Court is because political parties have carried out activities that are contrary to the Five Principles, the 1945 Constitution of the Republic of Indonesia, disrupting the Republic of Indonesia and proven to spread the ideology of communism and Leninism. In accordance with Article 68 paragraph (1) of Law No. 24 of 2003 concerning the Constitutional Court, the petitioner in the dissolution of political parties is the government8 and the respondent is a political party.

Since the Constitutional Court was established and given the authority to dissolve political parties, there has never been a political party dissolved by the Court. This reflects two reasons, namely the reason is limited to matters relating to the fight against ideology, the constitution and the Unitary Republic of Indonesia and the applicant is limited to the government. With regard to the reason for dissolution, in reality in Indonesia today formally, there are no more political parties who dare to oppose the ideology of Pancasila, the 1945 Constitution of the Republic of Indonesia, and the Republic of Indonesia. Facts on the ground actually show that the actual forms of violations committed by political parties are more on violations that are not regulated in statutory regulations, even 
though these actions clearly violate the laws and regulations and have a systemic impact on the administration of the state. An example is a political party that is proven to have violated elections that are structured, systematic and massive. In addition, regarding the granting of a single role to the government as petitioners for the dissolution of political parties is also felt to be problematic if clashed with the basic principles of democracy and is feared to be a tool of abuse of power by the government. For example, it is not impossible for the government to protect government political parties that have indicated problems, or rather the government proposes the dissolution of political parties that are opposed to government political parties.

The imposition of sanctions on political parties is divided into two, namely the imposition of administrative sanctions and the imposition of criminal sanctions. Understanding administrative sanctions can be seen through the understanding of sanctions in administrative law which explains that sanctions are a tool of public power (publiek rechtlijke michtsmiddelen) used by the authorities as a reaction to non-compliance with administrative legal norms. ${ }^{17}$

P. De Haan as quoted by Philipus M. Hadjon said that administrative law enforcement is often interpreted as the application of administrative law enforcement is often

17 Philipus M Hadjon, 1995, Penegakan Hukum Administrasi dalam Pengelolaan Lingkungan Hidup, paper, p. 1. interpreted as the application of administrative law. Sanctions are a tool of power (machtsmiddelen) as a reaction to violations of administrative legal norms. ${ }^{18}$ Whereas the imposition of criminal sanctions is one of law enforcement efforts using criminal law. Harbert L. Packer in his book The Limits Of Criminal Sanction, said: ${ }^{19}$

1. Criminal sanctions are absolutely necessary, we cannot live, now or in the future without criminal.

2. Criminal sanctions are the best tools or means available, which we have to

face the great dangers of immediate and to deal with threats from danger.

3. Criminal sanctions were at one time the "main or best guarantor", and at one time were the "main critics" of human freedom.

Muladi had stated that the trend of administrative law legislation still includes criminal sanctions is to strengthen the administrative sanctions (administrative penal law). The logic is that criminal sanctions should be utilized if administrative sanctions do not work. Especially those relating to criminal offenses that have gone too far and caused huge losses. ${ }^{20}$

Dissolution of political parties is the last legal remedy after

${ }^{18}$ Ibid ., p. 1.

${ }^{19}$ Barda Nawawi Arief, Kebijakan Legislatif dalam Penanggulangan Kejahatan Dengan Pidana Penjara, (Semarang: Badan Penerbit Undip, 1996), p. 28.

${ }^{20}$ Muladi, Kapita Selekta Sistem Peradilan Pidana, (Semarang: Badan Penerbit Undip, 1995), p. 42. 
administrative and criminal legal efforts have been carried out, this effort is one of the efforts made by the state against political parties that do not meet the requirements as political parties and carry out activities that result and are contrary to constitutional values.

Dissolution of political parties is a mechanism to stop the existence of political parties, which can be done through the dissolution of one's own decision, joining with other political parties, or dissolved based on state authority or as a result of new rules or state policies.

Dissolution of political parties is a limitation needed in democratic societies as a line of appreciation for the balance between public and private interests, these restrictions must be interpreted in a strict manner which includes, restrictions that must be regulated in the rule of law, restrictions imposed to achieve goals in society and restrictions that are proportional in accordance with social needs. ${ }^{21}$

In addition, the 2014 legislative elections were also considered the most vulgar in terms of giving money politics. The Police Version, there are 88 cases of money politics. Meanwhile, according to the People's Voter

\footnotetext{
21 Janusz Symonidess, Human Rights: Concept and standards, (AldershotBurlington USA-Singapore-Sydney: UNESCO Publishing, 2000, p a 1 a $\mathrm{m}$ an 91-91, in a dissertation Muchamad Ali Safa'at, Dissolution of Political Parties in Indonesia (Law and Practice Settings Analysis Dissolution of Political Parties 1959-2004), Graduate Program Faculty of Law, University of Indonesia, (2009), p. 25.
}

Education Network (JPPR), as many as $33 \%$ of polling stations in 25 Provinces in Indonesia are cheating money politics. Although money politics is carried out by legislative candidates (candidates), the candidate uses political parties as a vehicle to gain seats in representative institutions. If the candidate wins a seat and turns out to do money politics in the electoral process, then the political party to which the candidate is registered as a candidate must take responsibility. So far, sanctions for money politics have only been imposed on perpetrators who are individuals, while political parties have not been sanctioned. Supposedly, sanctions for money politics are not only imposed on candidates but also on political parties, both political parties as actors and political parties as places where money politics actors, in this case the candidates, are located.

However, what needs to be noted, in this idea, election violations that can be used as reasons for petition to dissolve political parties are only election violations which are violations of election law, such as money politics, vote manipulation, counterfeiting, mobilization of civil servants and cooperation with unscrupulous election candidates to obtain votes. In other words, election violations which are administrative violations are set aside as one of the reasons in the dissolution of political parties. This is in line as Bagus Sarwo said, which in essence said that: Election violations must be seen first whether it is a criminal offense and secondly whether the violations were carried out in a 
structured, systematic and massive manner. If all of this has been fulfilled, then it is not a problem if election violations that are criminal violations are used as an excuse in the dissolution of political parties. But if it is only an administrative violation, certainly dissolution is a sanction that is too heavy to be given.

Besides dealing with the expansion of the reasons for the dissolution of political parties as the researcher described above, the expansion of requests in the "petitioner" aspect of the dissolution of political parties is also an important thing for us to consider in the effort to create a more democratic system. As it is known that Article 68 paragraph (1) of Law no. 24 of 2003 concerning the Constitutional Court stated clearly that the petitioner for the case of the dissolution of political parties in the Constitutional Court was the Government represented by the Minister of the Interior or Attorney General. The authority of the government to become an applicant is related to the responsibility of the government to carry out the 1945 Constitution of the Republic of Indonesia and all applicable laws and regulations, and to strive for the sake of the constitution along with all the laws and regulations as well as possible in accordance with the law. Therefore, if a political party is deemed by the Government to have violated the Basic Law and / or legislation in force, it is the responsibility of the government to take the initiative to dissolve the political party concerned according to applicable legal procedures. But the question that then arises is, what if it turns out that precisely the government political parties are the problem? If this happens, it will certainly lead to potential conflicts of interest between the government and the relevant political parties which lead to the "impossibility" of the government taking the initiative to propose the dissolution of its own political party. If that really happened, of course this would damage the democratic values that exist in Indonesia. Thus, the researcher believes that it is not appropriate if the government is made as the sole petitioner in the proposal to dissolve political parties. For this reason, it is necessary to expand the application for the dissolution of political parties in Indonesia.

An extension of the petition for the dissolution of political parties can basically be given to individuals / community groups as the highest sovereignty implementers and the Election Supervisory Body (Bawaslu) in relation to the idea of researchers who seek to expand the reasons for the dissolution of political parties. The involvement of individuals / community groups as petitioners for the dissolution of political parties will certainly be relevant in an effort to realize a democratic electoral system. In a democratic election system, the people are positioned as the holders of the highest sovereignty, including in political life. In other words, the active involvement of the people in terms of supervision and evaluation of political parties becomes an inevitable necessity. Dissolution of political 
parties is a mechanism of supervision of political parties. This means that in a democratic election system the people should be given the right to propose the dissolution of political parties. Because by not involving the people as petitioners in the proposal to dissolve political parties, it is tantamount to "rejecting" the democratic electoral system itself.

\section{CONCLUSION}

Dissolution Mechanism of Political Parties by the Constitutional Court stipulated in Law OF No. 24 of 2003 on the Constitutional Court of the Republic of Indonesia to apply for dissolution stipulated in the Rules of Court Konstitu the Number 12 Year 2008 on Procedures Proceedings In the Dissolution of Political Parties.

The Extension of the Authority to Dissolve a Corrupt Political Party by the Constitutional Court is an offer of thought so that there is an effort to supervise from the public, especially the government to submit a request to dissolve a corrupt political party in Indonesia in order to establish a clean democratic system that is clean, honest and fair, by giving the authority to judge the constitutional court with amendment to the Constitution of the Unitary Republic of Indonesia or to provide an extension of the case that can be examined by the constitutional court through the Constitutional Court Law.

It should be given authority to the Constitutional Court of the Republic of Indonesia to accept and hear cases of petition for the dissolution of political parties on the grounds that the political party has committed a criminal act of corruption or the management of a political party that commits corruption in the interests of political parties as an institutional or legal entity.

\section{REFERENCES}

Arief, Barda Nawawi. Kebijakan Legislatif dalam

Penanggulangan Kejahatan Dengan Pidana Penjara, (Semarang: Badan Penerbit Undip, 1996).

$$
\text { Perbandingan Hukum }
$$

Pidana, Jakarta: Rajawali Pers, 1990.

Asshiddiqie, Jimly. Kemerdekaan Beserikat, Pembubaran Partai Politik dan Mahkamah Konstitusi, Sekretariat Jenderal dan Kepaniteraan Mahkamah Konstitusi Republik Indonesia, Jakarta.

, Pengantar Ilmu Tata Negara, (Jakarta: Rajawali Pers, 2009).

Hatrik, Hamzah. Asas

Pertanggungjawaban Korporasi dalam Hukum Pidana di Indonesia (Strict Liability dan Vicarius Liability), Jakarta: Grafindo Persada, 1996.

Muladi, Kapita Selekta Sistem Peradilan Pidana, (Semarang: Badan Penerbit Undip, 1995).

Philipus M Hadjon, Penegakan Hukum Administrasi dalam Pengelolaan Lingkungan Hidup, paper, Poerwadarminta, Kamus Umum Bahasa Indonesia, 1976.

Priyatno, Dwidja. Kebijakan Legislasi Tentang Sistem Pertanggungjawaban Pidana 
Korporasi Indonesia, Bandung: CV Utomo, 2004.

Putu Eva Ditayani Antari, Kewenangan Pembubaran Partai Politik Oleh Mahkamah Konstitusi Ditinjau Dari Persfektif Hak asasi Manusia (HAM), Jurnal Magister Hukum Udayana, Vol. 7, No. 3, 2014.

Reksodiputro, Mardjono. Pembaruan Hukum Pidana, Kumpulan Karangan, Buku Keempat, (Jakarta: Pusat Pelayanan Keadilan 59 dan Pengabdian Hukum Lembaga Kriminologi, Universitas Indonesia, 2007.

Roy C Macridis, Introduction: The History, Function, and Typology of Parties Contemporary Trends and Ideas", dalam Ichlasul Amal, Teori -Teori Mutakhir Partai Politik, (Yogyakarta: PT Tiara Wacana Yogya, 1998).

Santosa, Mas Achmad. Good Governance dan Hukum Lingkungan, (Jakarta: ICEL, 2001).

Soehino, Ilmu Negara, (Yogyakarta: Liberty, 2005).

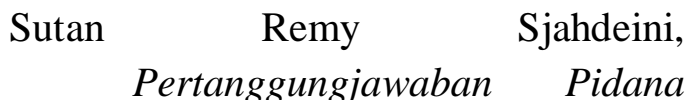
Korporasi, (Jakarta: Grafiti Pers, 2006).

Janusz Symonidess, Human Rights: Concept and standards, (Aldershot-

Burlington USA-SingaporeSydney: UNESCO Publishing, 2000, p a 1 a $\mathrm{m}$ an 91-91, in a dissertation Muchamad Ali Safa'at, Dissolution of Political Parties in Indonesia (Law and
Practice Settings Analysis

Dissolution of Political Parties 1959-2004), Graduate Program Faculty of Law, University of Indonesia, (2009).

Widayanti, "Pembubaran Partai Politk

Dalam Sistem Ketatanegaraan Indonesia”, Jurnal Hukum Univesotas Islam Sultan Agung, Vol. XXVI, No. 2, Agustus 2011. 